\title{
キャノピー内部の抗力係数分布を考慮した 樹木群を過ぎる流れの LES \\ LES OF VEGETATED OPEN CHANNEL FLOWS THAT TAKES INTO ACCOUNT THE DRAG COEFFICIENT DISTRIBUTION WITHIN CANOPY
}

\author{
横嶋 哲 ${ }^{1} \cdot$ 河原 能久 ${ }^{2}$ \\ Satoshi YOKOJIMA and Yoshihisa KAWAHARA \\ 1 正会員博 (工) 静岡大学准教授 大学院工学研究科数理システム工学専攻 (广 432-8561 浜松市中区城北 3-5-1) \\ 2 フェロー会員 工博広島大学教授 大学院工学研究科 社会基盤環境工学専攻 (₹ 739-8527 東広島市鏡山 1-4-1)
}

\begin{abstract}
The influence of the model drag coefficient on prediction accuracy of flows past emergent vegetation canopies by a classical canopy model has been examined. Two types of numerical simulations are carried out: The preliminary analysis based on a two-dimensional immersed boundary method gives an estimate of the spatial distribution of the drag coefficient over the vegetation canopy of the target flow. The estimated drag coefficient is introduced into the main analysis where a three-dimensional large-eddy simulation (LES) together with the canopy model is employed. The prediction accuracy of the main analysis is discussed against the corresponding experimental data and another LES result with a uniform drag coefficient in the canopy. The present LES with the estimated drag coefficient shows an improved prediction especially on stagnation phenomena at the leading edge of the vegetation patches. The improvement, however, is found mainly at the time-averaged flow level only. This is because the estimated drag coefficient is obtained from the time-averaged flow and does not reflect the instantaneous flow features directly.
\end{abstract}

Key Words: vegetated flow, drag, canopy model, drag coefficient, large eddy simulation, immersed boundary method, circular cylinders

1.はじめに

都市域における風環境や氾濫流解析, あるいは樹木 群を有する大気境界層や河川流の予測において, 個々の 構造物や植生要素の形状を織り込んで光の周囲の流れ を再現することは光も光も不可能であるか，あるいは 工学的に許容できないコストを要することが多く，障 害物の特性を何らかのパラメータで適切に表現, モデ ル化することか強く望まれる.一般に見付面積が $A$, 抗 力係数が $C_{\mathrm{D}}$ の任意の物体に作用する力 $\vec{F}$ は次式で表 される :

$$
\vec{F}=\frac{1}{2} \rho C_{\mathrm{D}} A|\vec{u}| \vec{u} .
$$

ここで $\vec{u}, \rho$ は流体の速度および密度を表す．よって， この物体が単位体積当たりの流体に及ぼす力 $\vec{f}$ は

$$
\vec{f}=-\frac{\vec{F}}{V}=-\frac{1}{2} \rho C_{\mathrm{D}} \lambda|\vec{u}| \vec{u}
$$

のように近似でき，いわゆる抗力モデルとして，非常 に多くの適用例が報告されている．ここで $V$ は物体体 積を表し，入は障害物の表面積密度と呼ばれる。

障害物群落が幾何学的に単純であれば表面積密度 $\lambda$ はその定義に基づいて一意に決まるのに対して, 適切 な抗力係数 $C_{\mathrm{D}}$ を導く標準的な手法は単純な樹木群模型 に対しても存在せず，このアプローチのボトルネック
と言える . 著者ら ${ }^{1)}$ は樹木群模型を過ぎる直線開水路 流れのラージ・エディ・シミュレーション (LES) にお いて, 樹木群内部のモデル抗力係数としてある値を一 樣に与えた場合, 樹木群が主流方向に連続するケース での LES の予測精度は極めて高い反面, 樹木群が主流 方向にパッチ状に配置された場合の流れ特性の再現性 は不十分であることを報告している．特に，樹木群領 域前縁で流れがせき止められ，側面に回り込むよどみ 現象が十分に再現されないことが確かめられている .

樹木群密度 $\lambda$ が一樣な場合, 抗力係数 $C_{\mathrm{D}}$ はチュー二 ング可能な唯一のモデルパラメータである . 本研究で は午の抗力係数の樹木群内部での空間分布の影響を考 慮することでモデルの再現性がどう変化するのかを検 討する . 樹木群内部での抗力係数分布を見積もる方法 として, 埋め込み境界法に基づく 2 次元数値解析を利 用する. 対象とする流れを 2 次元解析 (予備解析) に よって近似的に, しかし個々の樹木要素周りの流れを 解像する形で再現し, 求まった個々の要素に働く流体 力から, 3 次元 LES (主解析) で用いる抗力係数分布を 推定する . 兴のようなアプローチはすでに著者ら ${ }^{2)} に$ よって検討がなされてきたものの, 光こでは予備解析， 本解析ともに 2 次元流れが対象であった . 弚れに対し て, 本研究における主解析の対象は実験水路で実際に 観測された 3 次元乱流場である . 


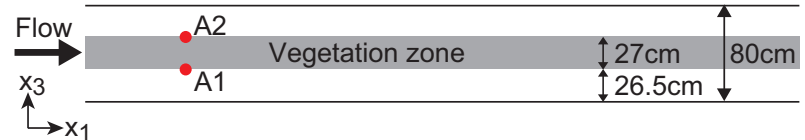

(a) Case 1 .

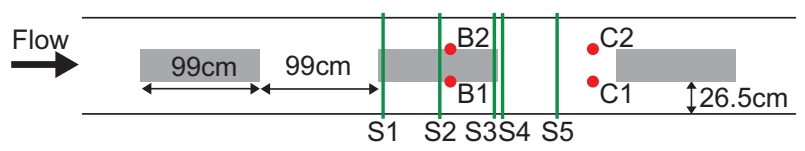

(b) Case 2 .

図-1 検討対象とした樹木群を有する直線開水路流れの概要. 断面 S1-S5 は図-6に示す流速分布の評価断面位置を, 点 $\mathrm{A1} 1, \mathrm{A2}, \mathrm{B} 1, \mathrm{~B} 2, \mathrm{C1}, \mathrm{C} 2$ は図-7-図-10に示す時系列データの評価位置をそれぞれ表す.

表-1 2 次元 IBM 予備解析の計算条件. 長さと時間の単位は全て $\mathrm{cm}$ と $\mathrm{sec}$.

\begin{tabular}{|c|c|c|c|c|c|c|c|c|c|}
\hline & \multirow[b]{2}{*}{$R e_{\mathrm{D}}$} & \multicolumn{2}{|c|}{ Domain size } & \multicolumn{2}{|c|}{ \# of grid points } & \multicolumn{2}{|c|}{ Grid spacing } & \multirow[b]{2}{*}{$T$} & \multirow[b]{2}{*}{$\Delta t$} \\
\hline & & $L_{1}$ & $L_{3}$ & $n_{1}$ & $n_{3}$ & $\Delta x_{1}$ & $\Delta x_{3}$ & & \\
\hline All cases & 700 & 198 & 80 & 7920 & 1274 & 0.025 & $0.025-0.50$ & 64.3 & $2.01 \times 10^{-4}$ \\
\hline
\end{tabular}

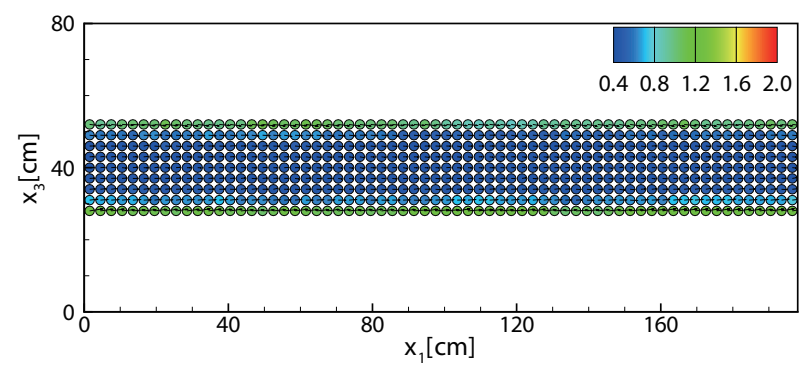

(a) Case 1 .

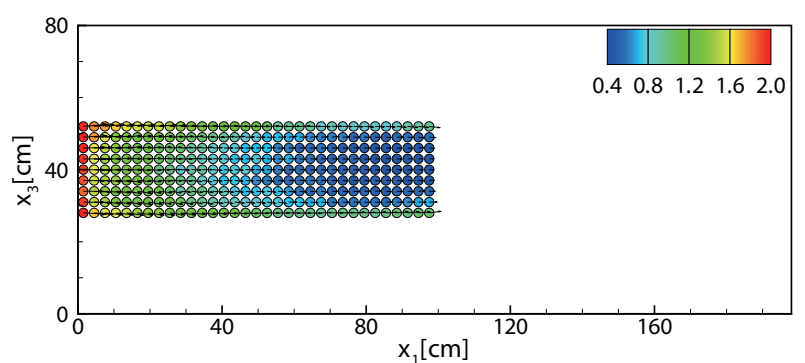

(b) Case 2 .

図-2 予備解析から求まった各円柱の時間平均抗力係数の分布.

\section{2. 検討対象流れと数值解析法の詳細}

\section{(1) 検討対象流れ}

全長 $24 \mathrm{~m}$ ，幅 $80 \mathrm{~cm}$ の直線水路上に，中心間距離 $s$ を $3 \mathrm{~cm}$ として正方格子状に配置された直径 $D=3 \mathrm{~mm}$ の円柱からなる樹木群模型を過ぎる流れを検討対象と した . 概略図を図-1に示す . 幅 $27 \mathrm{~cm}$ の樹木群模型を 主流方向に連続的に水路中央に沿って配置した場合を Case 1, $99 \mathrm{~cm} \times 27 \mathrm{~cm}$ の樹木群を $99 \mathrm{~cm}$ 間隔で主流方向 に離散的に配置した場合を Case 2 とする.いずれの場 合にも水路上流端から $12 \mathrm{~m}$ 下流の, 十分に発達した流 れを検討対象とした . 流量を $91 / \mathrm{s}$ としたときの平均水 深は Case 1 の場合に $4.78 \mathrm{~cm}$, Case 2 の場合に $4.71 \mathrm{~cm}$ となり, 樹木群模型は常に非水没な状態にあった．

\section{（2）埋め込み境界法に基づく 2 次元予備解析}

抗力モデルを用いた 3 次元 LES による主解析に適切 な抗力係数分布を与えるための予備解析では, 埋め込み 境界法 (IBM) によって個々の樹木要素周りの流れを解 像し, 流体力を評価した . 本研究で用いた IBM の詳細 と产の基本性能については文献 ${ }^{2,3,4)}$ を参照されたい .

計算条件を表-1にまとめた . 主解析では主流方向に $594 \mathrm{~cm}$ の計算領域を確保するのに対して，予備解析で は光の $1 / 3$ で, Case 2 の幾何学的最小ユニットとなる $198 \mathrm{~cm}$ を計算領域とした .このとき, Case 1 では 594 (= $66 \times 9)$ 本の, Case 2 では光の半分の 297 本の円柱が解析 領域に含まれる.計算格子は主流 $x_{1}$ 方向には等間隔に， 水路横断 $x_{3}$ 方向には円柱群領域内部 $\left(26.5 \mathrm{~cm} \leq x_{3} \leq\right.$ $53.5 \mathrm{~cm})$ および側壁極近傍で最も解像度が高く，円柱 直径 $D$ の $1 / 12$ 倍 $(=0.25 \mathrm{~mm})$ とした .これによって
計算格子点数は $7920 \times 1274$ となった . 主流方向には周 期境界条件を，水路側壁および円柱表面では粘着・不 透過条件を課した。

Case 1 および Case 2 の実験結果 ${ }^{1)}$ によれば水表面で の断面平均流速 $U_{\mathrm{b}}$ と円柱直径に基づくレイノルズ数 $R e_{\mathrm{D}}$ は約 700 であったので, 予備解析でも主流方向の 平均圧力勾配を制御することで $R e_{\mathrm{D}}=700$ を常に保つ ようにした . 単一円柱を過ぎる流れにおいては, $R e_{\mathrm{D}}$ が 200 を超えるあたりから流れの 3 次元性は現れると指 摘されている ${ }^{5)}$.ただし，この予備解析の目的は樹木群 領域内である単一の抗力係数值を一樣に与える従来の 方法 ${ }^{1)}$ を少しでも合理性の高い手段で置き換える点に ある . また , 竹岡ら ${ }^{6)}$ (平板間に設置された円柱群を 過ぎる流れにおいて， $R e_{\mathrm{D}}=5-1000$ の範囲での摩擦 損失係数の分布を 2 次元 IBM 解析によって良好に再現 している．今回の予備解析では時間刻み幅 $\Delta t$ を約 0.2 ミリ秒とし，統計的に定常な状態に至った後に 60 秒強 に渡るデータサンプリングを行った .

各円柱に働く時間平均抗力から得られた，断面平均 流速 $U_{\mathrm{b}}$ と円柱直径 $D$ に基づく時間平均抗力係数の分布 を図-2 に示す .この図では円柱は実際の大きさよりも 誇張して示されていることに注意されたい. 樹木群が 主流方向に連続する Case 1 では, 強いせん断が生じる 植生界面で抗力係数が 1 前後のやや高い値をとる反面， 水路中央付近では 0.4 に達しない . 樹木群がパッチ状に 配置された Case 2 では樹木群前縁で流れがせき止めら れて圧力が高まることで強い抗力が生じること，およ び下流側の円柱に働く抗力は上流側の円柱の遮蔽効果 によって軽減されることが認められる . Case 2 におけ る抗力係数の最大值，最小值は光れ攵れ約 $2.20 ， 0.34$ 


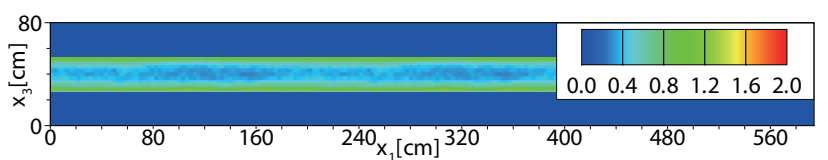

(a) Case 1 .

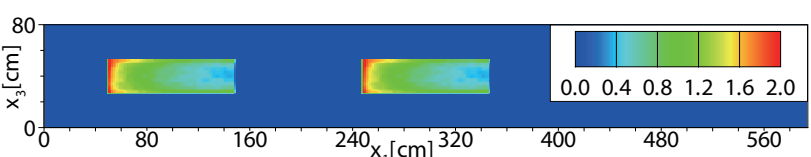

(b) Case 2 .

図-3 主解析で使用したモデル抗力係数の分布.

表-2 3 次元 LES 主解析の計算条件. 長さと時間の単位は全て $\mathrm{cm}$ と $\mathrm{sec}$.

\begin{tabular}{|c|c|c|c|c|c|c|c|c|c|c|c|c|}
\hline & \multirow[b]{2}{*}{$R e_{\mathrm{b}}$} & \multicolumn{3}{|c|}{ Domain size } & \multicolumn{3}{|c|}{$\#$ of grid points } & \multicolumn{3}{|c|}{ Grid spacing } & \multirow[b]{2}{*}{$T$} & \multirow[b]{2}{*}{$\Delta t$} \\
\hline & & $L_{1}$ & $L_{2}$ & $L_{3}$ & $n_{1}$ & $n_{2}$ & $n_{3}$ & $\Delta x_{1}$ & $\Delta x_{2}$ & $\Delta x_{3}$ & & \\
\hline Case 1 & 11250 & 594 & 4.78 & 80 & 480 & 37 & 194 & 1.238 & $0.013-0.314$ & $0.014-0.504$ & 120.9 & $3.56 \times 10^{-3}$ \\
\hline Case 2 & 11250 & 594 & 4.71 & 80 & 480 & 36 & 194 & 1.238 & $0.014-0.317$ & $0.014-0.504$ & 120.9 & $3.56 \times 10^{-3}$ \\
\hline
\end{tabular}

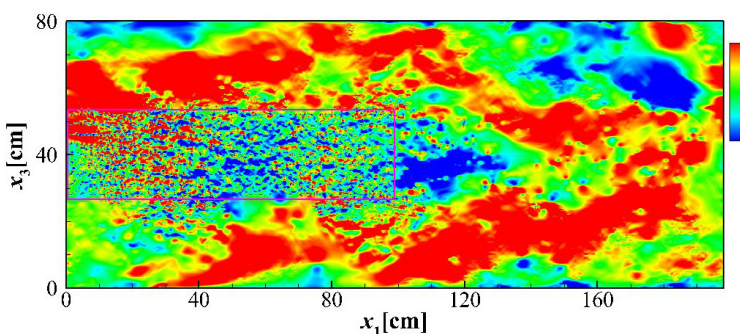

(a) an instantaneous snapshot, 2-D IBM analysis.

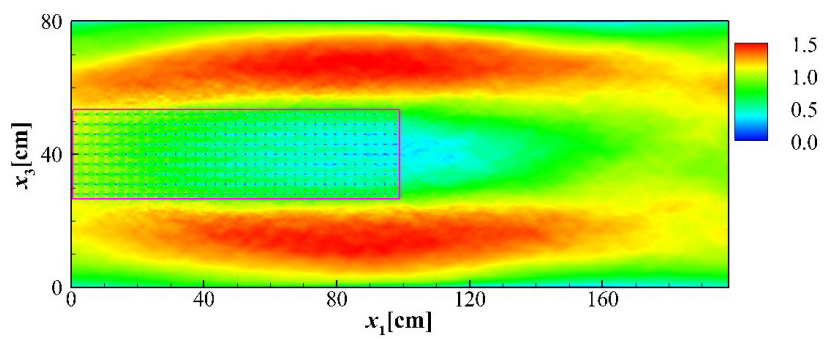

(c) the time averaged , 2-D IBM analysis.

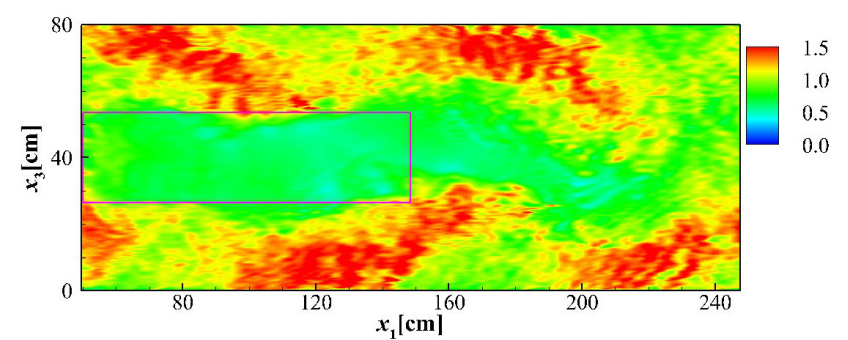

(b) an instantaneous snapshot, 3-D LES analysis.

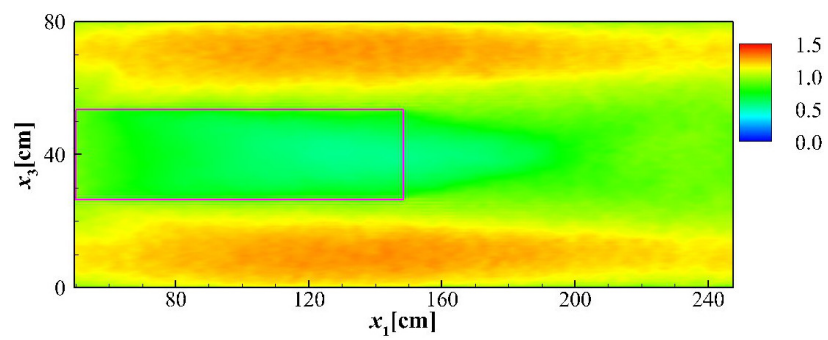

(d) the time average, 3-D LES analysis.

図-4 2 次元 IBM 予備解析および 3 次元 LES 主解析から得られた, Case 2 における水平 $x_{1}-x_{3}$ 面内での主流速分布. 断面平 均流速 $U_{\mathrm{b}}$ で無次元化されている.

となった . Neary et al. ${ }^{7)}$ は円柱直径と中心間距離の比 $D / s$ が樹木群の粗密の分類に有用であり， $D / s \leq 0.1$ の 場合には円柱間の相互干渉の影響は無視できることを 述べたが, 本予備解析の結果は彼らの指摘が必ずしも 全てのケースに当てはまらないことを示唆している .

\section{(3) 抗力モデルを用いた 3 次元 LES 主解析}

3 次元 LES による主解析では, サブグリッドスケー ル応力を標準スマゴリンスキーモデルで , 樹木群の存 在が流れに及ぼす影響を式 (2)で表現される抗力モデル で, 光れ近似した . 抗力モデルのパラメータのひ とつである樹木群密度 $\lambda$ は光の定義より $1 / 30 \mathrm{~cm}^{-1}$ と 求まる.もうひとつのパラメータのモデル抗力係数に ついては，(2) 節で導入した 2 次元 IBM に基づく予備 解析から得られた水平面内での離散的な抗力係数分布 (図-2) を逆距離加重 (IDW) 法を用いて円柱群領域全 体に補間することによって得た（図-3) . 補間にIDW 法を用いた理由は, 推定値が測定値 (IBM 解析より得 られた各円柱の抗力係数) の最大・最小値を超えない ためである . なおモデル抗力係数は水深 $x_{2}$ 方向には一 樣に分布すると仮定した .
主解析の計算条件を表-2 に示す．水路床および側壁 近傍には計算格子点を集中させ，粘着・不透過条件を課 した・壁に隣接する計算格子のサイズは約 3.6 粘性長で ある.他方で樹木群領域では主流方向，横断方向に关

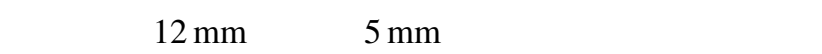
を構成する円柱直径 $3 \mathrm{~mm}$ よりも広い, 等間隔格子を用 いた．時間刻み幅 $\Delta t$ を約 3.6 ミリ秒とし，120 秒強に 渡ってデータサンプリングを行い，統計量を評価した。

図-4に，2 次元 IBM 予備解析および 3 次元 LES 主 解析から得られた, Case 2 における水平 $x_{1}-x_{3}$ 面内 での主流速分布を示す . (a), (b) はある瞬間のスナップ ショットを, (c), (d) は時間平均值を表し, 3 次元 LES で は水表面上で得られた結果を示す .なお, 以下の議論 は Case 1 にも当てはまるものである. 瞬時場 , 時間平 均場ともに大まかな構造は似通っているものの, IBM 解析では LES に比べてより強い極值分布が認められる． この理由として，IBM 解析では個々の円柱による排除 体積効果が直接的に表現されるため, 抗力モデルに基 づくLES では生じない流体の局所的な加減速が再現さ れること, および本研究では主解析の抗力モデルに与 えるモデル抗力係数を断面平均流速 $U_{\mathrm{b}}$ を基準流速とし 


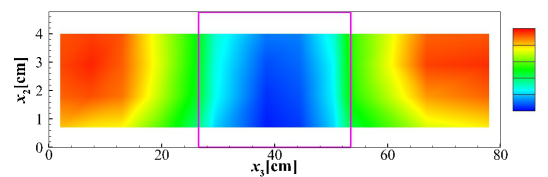

(a) experiment ${ }^{1)}$.

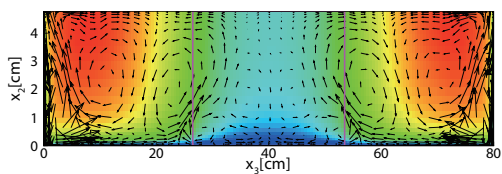

(b) $\mathrm{LES}^{1)}, C_{\mathrm{D}}=0.6$.

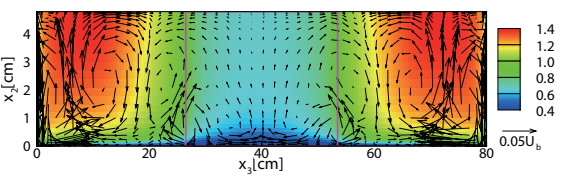

(c) present LES, $C_{\mathrm{D}}$ given by Fig. 3(a).

図-5 Case 1 における平均流速分布.

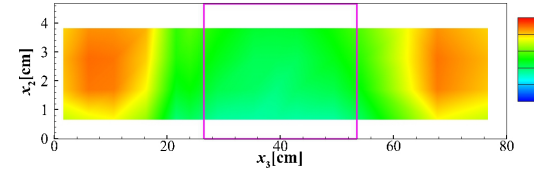

(a) experiment ${ }^{1)}$

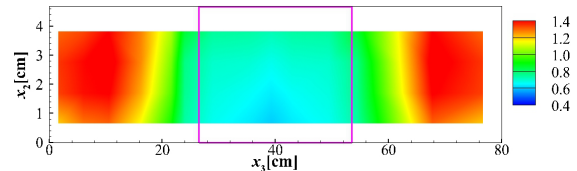

(d) experiment ${ }^{1)}$

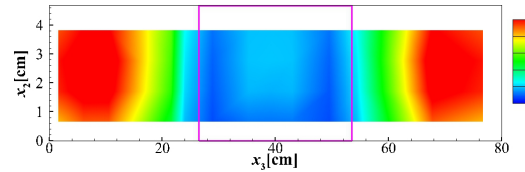

(g) experiment ${ }^{1)}$

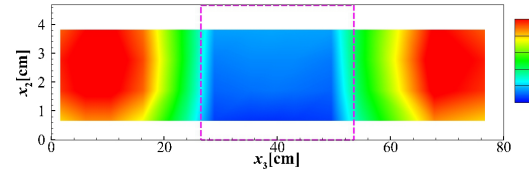

(j) experiment ${ }^{1)}$.

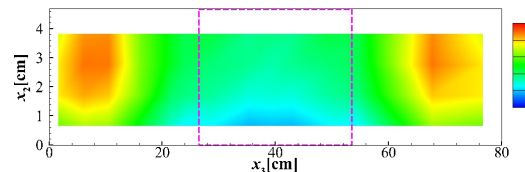

(m) experiment ${ }^{1)}$.

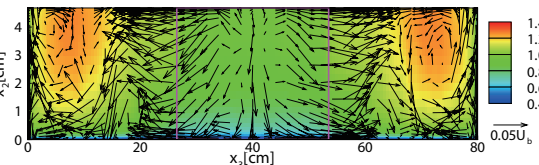

(b) $\mathrm{LES}^{1)}, C_{\mathrm{D}}=1.0$.

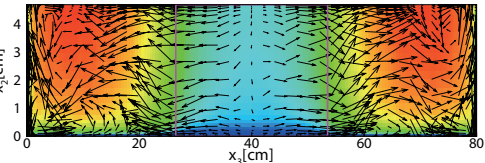

(e) $\mathrm{LES}^{1)}, C_{\mathrm{D}}=1.0$.

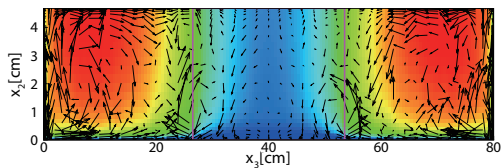

(h) $\mathrm{LES}^{1)}, C_{\mathrm{D}}=1.0$.

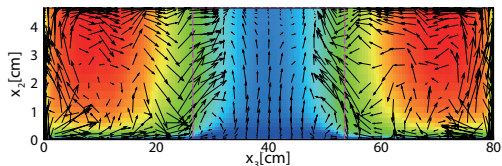

(k) $\mathrm{LES}^{1)}, C_{\mathrm{D}}=1.0$.
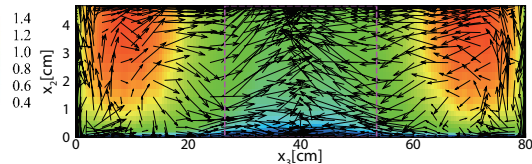

(n) $\mathrm{LES}^{1)}, C_{\mathrm{D}}=1.0$.

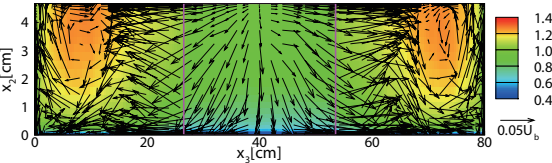

(c) present LES, $C_{\mathrm{D}}$ given by Fig. 3(b).

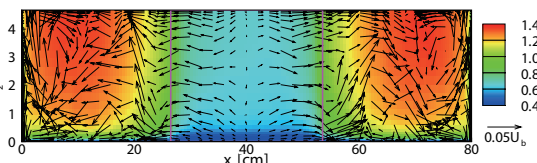

(f) present LES, $C_{\mathrm{D}}$ given by Fig. 3(b).

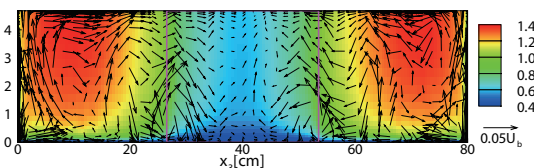

(i) present LES, $C_{\mathrm{D}}$ given by Fig. 3(b).

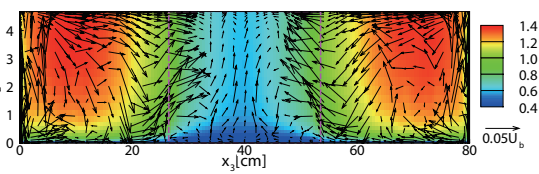

(1) present LES, $C_{\mathrm{D}}$ given by Fig. 3(b).

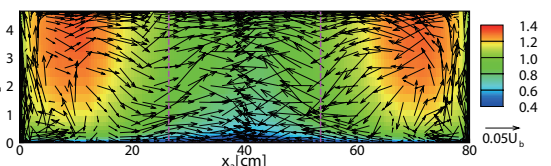

(o) present LES, $C_{\mathrm{D}}$ given by Fig. 3(b).

図-6 Case 2 における平均流速分布. (a)-(c) は図-1(b) の断面 S1，(d)-(f) は断面 S2，(g)-(i) は断面 S3，(j)-(l) は断面 S4，(m)-(o) は断面 S5 における結果を示す.

て算出しているため, 樹木群内の中・下流領域に位置す る円柱については抗力係数が過小評価となっていると 推察されること，が挙げられる. 後者については，個々 の円柱に対する適切な接近流速に基づく抗力係数を評 価することを今後の課題としたい .

次節では，図-3に示したモデル抗力係数の空間分布 を考慮することで，LES による流れの再現性がどの程 度改善されるのかを，対応する実験結果および均一な モデル抗力係数を課した LES 結果 ${ }^{1)}$ との比較によって， 検討する .なお，IBM 予備解析における全ての円柱の 時間平均抗力係数 (図-2) の算術平均值は Case 1 では 0.59 , Case 2 では 0.92 であったので, 上述の均一なモ デル抗力係数の值はこれらに近い值である，Case 1 で 0.6 , Case $2 て ゙ 1.0$ とする .これらの值を用いた LES 結 果, および均一なモデル抗力係数の值の変化が流れの再

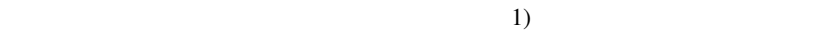

\section{3. 結果と考察}

\section{(1) 時間平均流れ}

Case 1 における主流に垂直な $x_{2}-x_{3}$ 断面内での平均流 速分布を図-5に示す . (a) は実験結果を，(b), (c) はとも にLES 結果を表し，(b) では樹木群内部で $C_{\mathrm{D}}=0.6$ の 一樣分布を，(c) では図-3(a) の抗力係数分布を与えた . 図-5(c) では (b) に比べて断面内の二次流か強められ，樹 木群内外での主流速の差が大きい .

Case 2 において，図-1(b) で示される 5 断面 (S1-S5) で得られた平均流速分布を図-6に示す. 左は実験結果 を，中央は $C_{\mathrm{D}}=1.0$ の一樣分布を与えた LES 結果を， 右は図-3(b) の抗力係数分布を導入した LES 結果を光れ ぞれ表す．流れが樹木群に遭遇した直後の断面 S1 では， 抗力係数分布を考慮した (c) の場合に植生内部から水路 両サイドに流体が回り込む傾向が強まること，および 光の少し下流の断面 S2 では抗力係数が一樣な (e) の結 果に比べて樹木群内外の主流速の差が大きくなること が認められる．流れが樹木群を去る断面 S3 および S4 では，抗力係数分布を考慮した LES 結果において両サ 


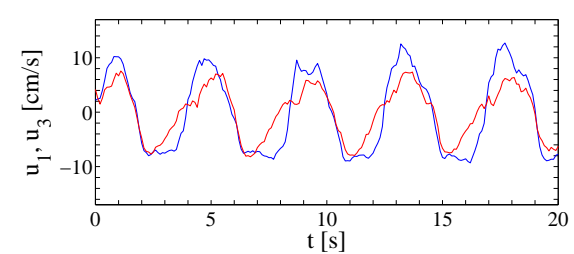

(a) experiment ${ }^{1)}$.

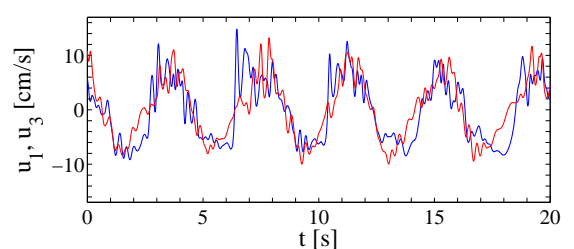

(b) $\mathrm{LES}^{1)}, C_{\mathrm{D}}=0.6$.

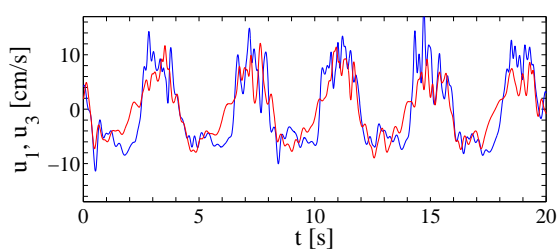

(c) present LES, $C_{\mathrm{D}}$ given by Fig. 3(a).

図-7 Case 1 において, 点 $\mathbf{A 1}$ で得られた流速 $u_{1}$ および $u_{3}$ の時系列分布: 青, $u_{1}$; 赤, $u_{3}$. 実験では $x_{2}=2.5 \mathrm{~cm}($ 水路床で $\left.x_{2}=0 \mathrm{~cm}\right)$ で, LES では $x_{2}=2.55 \mathrm{~cm}$ で計測が行われた.

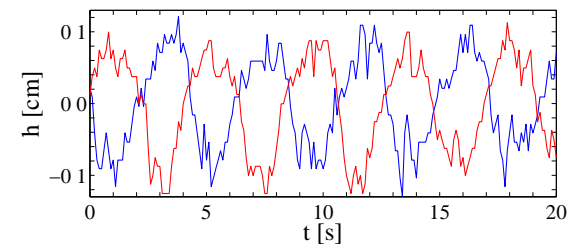

(a) experiment ${ }^{1)}$.

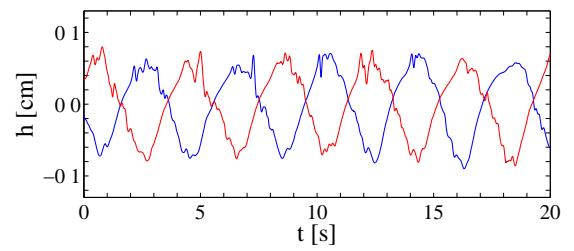

(b) $\mathrm{LES}^{1)}, C_{\mathrm{D}}=0.6$.

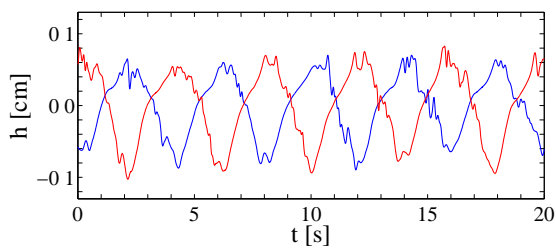

(c) present LES, $C_{\mathrm{D}}$ given by Fig. 3(a).

図-8 Case 1 において, 点 A1, A2 で得られた水面変動の時系列分布. LES における水面変動は水面圧力に静水圧近似を適用 して得られた.

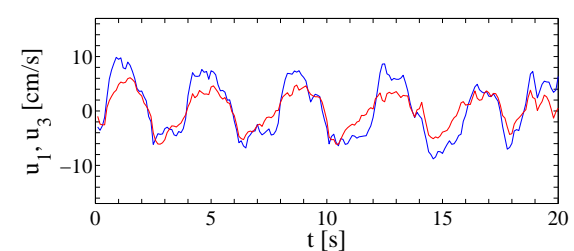

(a) experiment ${ }^{1)}$.

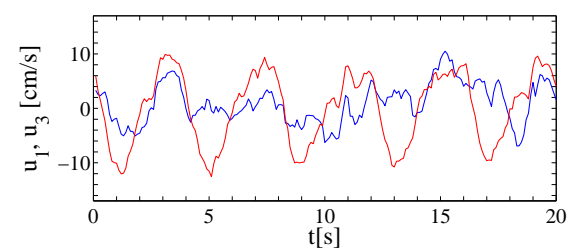

(d) experiment ${ }^{1)}$.

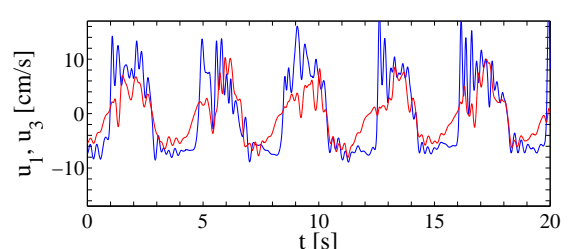

(b) $\mathrm{LES}^{1)}, C_{\mathrm{D}}=1.0$.

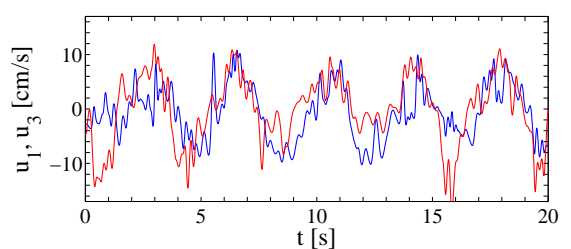

(e) $\mathrm{LES}^{1)}, C_{\mathrm{D}}=1.0$.

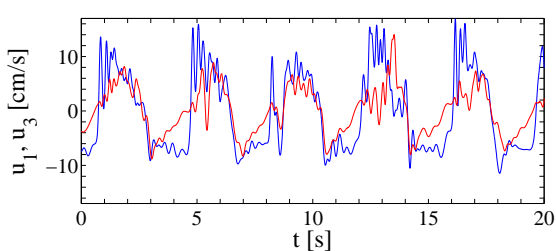

(c) present LES, $C_{\mathrm{D}}$ given by Fig. 3(b).

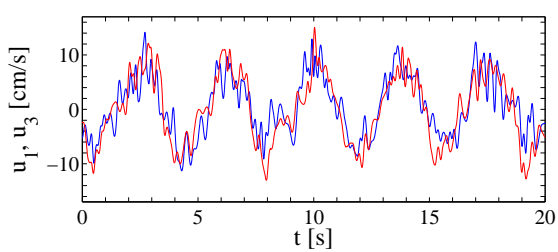

(f) present LES, $C_{\mathrm{D}}$ given by Fig. 3(b).

図-9 Case 2 において, 点 B1（ (a)-(c)）および点 C1（ (d)-(f)）で得られた流速 $u_{1}$ および $u_{3}$ の時系列分布: 青, $u_{1}$; 赤, $u_{3}$. 実験 では $x_{2}=2.5 \mathrm{~cm}\left(\right.$ 水路床で $\left.x_{2}=0 \mathrm{~cm}\right)$ で, LES ゙゙ $x_{2}=2.65 \mathrm{~cm}$ で計測が行われた.

イドから水路中央への流体の回帰が促進され，樹木群 下流端から $40 \mathrm{~cm}$ 強下流の断面 S5 では, (o) において 断面内での速度差がより緩和されている樣子が伺える

\section{(2) 瞬時流れ}

Case 1 において図-1(a) に表示された点 A1 で得られ た主流および横断方向瞬間流速の時系列分布を図-7に 示す. 実験 ${ }^{1)}$ で用いた電磁流速計の時間分解能はせい ぜい $5 \mathrm{~Hz}$ 程度であり，時間刻み幅 $\Delta t$ が数ミリ秒である LES には遠く及ばないことに留意されたい， $u_{1}$ と $u_{3}$ の 位相が一致する現象はいずれのLES でも再現されてい るが, 抗力係数を図-3(a)のように与えた (c) の結果に おいては, 主流速 $u_{1}$ の極大值が横断成分 $u_{3}$ の極大值 を上回るという実験結果に見られる傾向も捉えられて いる. 図-8 に点 $\mathrm{A} 1$ および $\mathrm{A} 2$ て計測された水面変動の 時系列分布を示す. LES では水面位置での瞬時圧力に 静水圧近似を適用して水面変動を見積もつた．モデル 抗力係数の与え方によって水面変動の時系列の予測に 有意な差異は見出されないものの, LES 結果は共に水
面変動を実験結果よりも過小に再現する . 樹木群内部 で一樣なモデル抗力係数を今回よりもやや高い 0.8 と した場合には LES 結果と実験結果は定量的にもよりよ 〈一致する ${ }^{1)}$ ことから，予備解析における抗力係数の 評価の際に個々の円柱に対するより適切な接近流速を 用いることで，このLES による水面変動の過小評価の 傾向は改善される可能性がある .

次にCase 2 における瞬間流速の時系列分布を図-9に， 水面変動の時系列分布を図-10に光れ光れ示す. 弚れ光 れの図の (a)-(c) は図-1(b) の点 B1 (水面変動について は点 $\mathrm{B} 2$ も含む) で, (d)-(f) は点 $\mathrm{C} 1$ (水面変動につい ては点 $\mathrm{C} 2$ も含む）におけるデータサンプリングから得 られたものである.実験結果においては，Case 1 でも 観察されたように樹木群内部では $u_{1}$ と $u_{3}$ の位相がほ ほ揃い, 樹木群の両縁での水面変動が逆位相となるの に対して，樹木群間のギャップでは水路の両サイドで発 達した大規模水平渦が互いに干渉するため, 弚れらの 位相差には時折ズレが認められる．また，樹木群が存 在しない点 $\mathrm{C} 1$ では横断方向成分の変動 $u_{3}$ が強められ， 


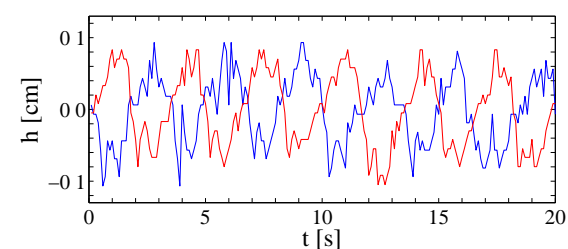

(a) experiment ${ }^{1)}$.

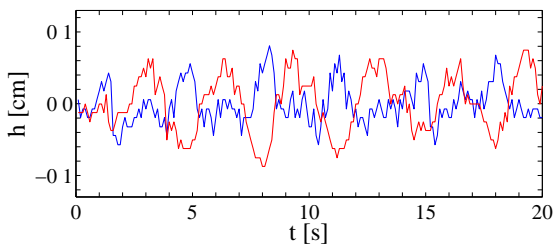

(d) experiment ${ }^{1}$.

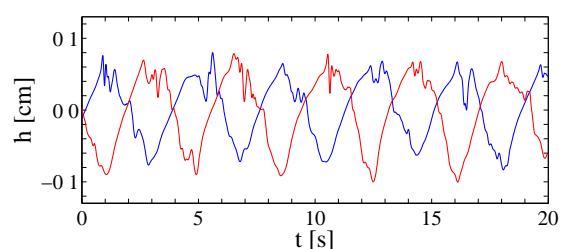

(b) $\mathrm{LES}^{1)}, C_{\mathrm{D}}=1.0$.

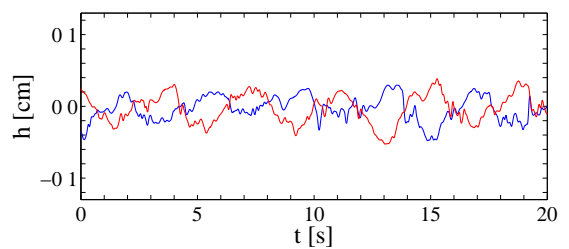

(e) $\mathrm{LES}^{1)}, C_{\mathrm{D}}=1.0$.

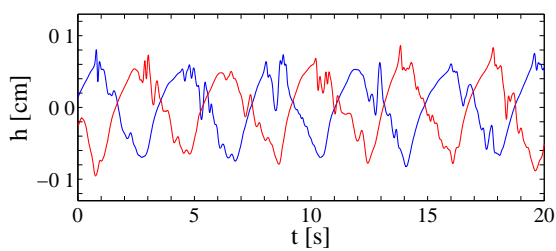

(c) present LES, $C_{\mathrm{D}}$ given by Fig. 3(b).

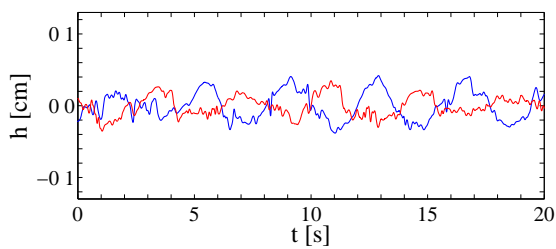

(f) present LES, $C_{\mathrm{D}}$ given by Fig. 3(b).

図-10 Case 2 において, 点 B1, B2（（a)-(c)）および点 C1, C2（（d)-(f)）で得られた水面変動の時系列分布. LES における水面 変動は水面圧力に静水圧近似を適用して得られた.

横断方向への運動量輸送が活性化されることが伺われ る.こういった傾向がLES で再現されたとは言い難い 先に示した図-4(a), (b) からは, 2 次元 IBM 予備解析で は瞬時場における樹木群ギャップでの水路両サイドの大 規模水平渦の干渉が活発に発生しているのに対して，3 次元 LES 主解析結果では両者が本格的に干渉する前に 次の樹木群に遭遇する樣子が伺われる. 予備解析から 主解析に抗力係数分布を通じて反映されるのはあくま でも時間平均流の構造であり，瞬時流レベルでの流れ 特性の再現性の改善まではあまり期待できないことを 示唆するものと考えられる .

\section{4. おわりに}

植物群落や都市境界層といった複雑なキャノピー層 を過ぎる流れを効率的に行う上で，抗力モデルの導入 は依然として有力なアプローチである. 本研究では抗 カモデルのパラメータのひとつである抗力係数のキャ ノピー層内部での空間分布の影響を考慮することで流 れの再現性がどの程度改善されるのかを，樹木群模型 を過ぎる開水路流れの LES 解析によって検討した .

樹木群模型内部の抗力係数分布を, 2 次元解析ではあ るものの, 個々の樹木要素周りの流れと個々の要素に働 く流体力を埋め込み境界法 (IBM) で再現 (予備解析) することで推定した . 得られた抗力係数分布に基づく LES 結果 (主解析) を, 対応する水理実験結果 ${ }^{1)}$ およ び抗力係数を均一に与えた LES 結果 ${ }^{1)}$ と比較した。

抗力係数を均一に与えた LES では, 樹木群が水路上 にパッチ状に分布する場合に，樹木群前面での流れのよ どみや樹木群側面への回り込み現象の再現性が弱いこ とが報告されているが，抗力係数分布を考慮した LES 結果ではこれらの点について改善が確かめられた . 他 方で, 予測精度の向上か認められたのは時間平均流レ ベルに限られ，瞬時流れにおいては実験結果が示す特 性を捉えられない例も示された . これは 2 次元予備解 析から 3 次元主解析に抗力係数分布を通じて与えられ た情報はあくまでも時間平均流レべルのものであるた
めと理解できる .

2 次元 IBM 予備解析から得られた抗力係数は断面平 均流速を基準速度として算出されており，樹木群内の 中・下流部に位置する円柱については抗力係数が過小 評価となっていると推察される. 個々の円柱に対して 適切な接近流速を用いることによる主解析の結果の改 善の可能性については今後の検討課題である .

謝辞: 本研究の一部は, 科学研究費補助金 基盤研究 (B) (課題番号 23360215 , 代表 : 河原能久), 若手研究 (B) (課題番号 23760456 , 代表 : 横嶋 哲)，および高橋産 業経済研究財団 (代表 : 横嶋哲) の支援を受けて行わ れた 、ここに記して謝意を表する。

\section{参考文献}

1) Yokojima, S., Kawahara, Y., and Yamamoto, T.: Impacts of vegetation configuration on flow structure and resistance in a rectangular open channel, J. Hydro-environmental Res., in press.

2) 横嶋 哲, 河原 能久: 円柱群を過ぎる 2 次元流れに対する抗 力モデルの適用性, 土木学会論文集 A2, 印刷中.

3) 横嶋 哲, 野田 博, 河原 能久: 円柱群を過ぎる 2 次元流れの 抗力特性, 土木学会論文集 B1, 70(4), pp.I_829-I_834, 2014.

4) Uhlmann, M.: An immersed boundary method with direct forcing for the simulation of particulate flows, J. Comput. Phys., Vol.209, pp.448-476, 2005.

5) Williamson, C.H.K.: Vortex dynamics in the cylinder wake, Annu. Rev. Fluid Mech., Vol.28, pp.477-539, 1996.

6) 竹岡佑介, 重松 孝昌, 中條壮大: IB 法を用いた円柱群 通過流れの 2 次元数值シミュレーション, 混相流, 24(5), pp.689-696, 2011.

7) Neary, V.S., Constantinescu, G., Bennett, S.J., and Diplas, P.: Effects of vegetation on turbulence, sediment transport, and stream morphology, J. Hydraul. Eng., Vol.138(9), pp.765776, 2012.

（2014.9.30 受付） 